https://doi.org/10.24101/logos.2020.38

Gauta 20190920

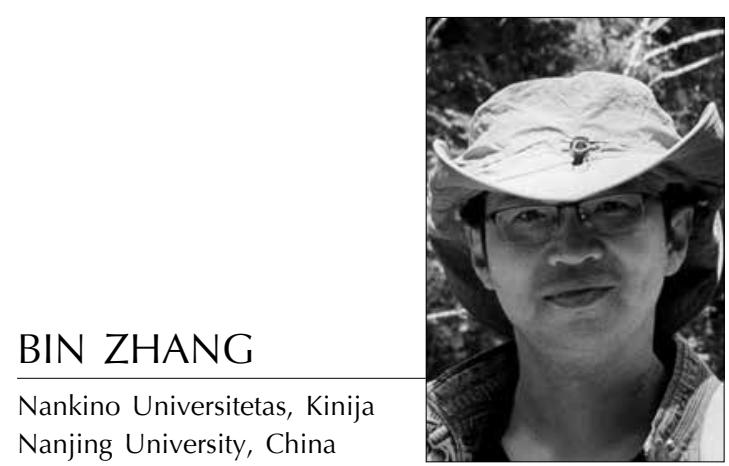

\title{
ANKSTYVIEJI KONFUCIANISTAI IR IMPERATORIŠKIEJI MUZIKOS VALDININKAI
}

\author{
Early Confucians and Imperial Music Officials
}

\begin{abstract}
SUMMARY
By using ethimological analysis and relying on historical documents, this article attempts to answer the question of the significance of music in the Confucian tradition of thought and action. The analysis reveals the tight relation between the Confucian tradition, especially the early Confucians who are named the "Ruists", and the imperial music officials. The class of imperial music officials prospered even before the Zhou dynasty, and they were in charge of the state's music, rites and education. As an important ruist tradition inheritor and representative, Confucius used these three vectors (music, sites and education) as fundamental principles for later Confucianism.
\end{abstract}

\section{SANTRAUKA}

Straipsnyje atliekama etimologinė ir istorinių dokumentų analizė siekiant atsakyti i klausimą, kodèl muzika ir su ja susijusi harmonijos sąvoka yra tokios svarbios konfucianizmo minties ir veiksmo tradicijoje. Atskleidžiamas konfucianizmo tradicijos, ypač ankstyvujjų konfucianistų, vadinamų ruistais, glaudus ryšys su imperatoriškaisiais muzikos valdininkais. Imperatoriškųjų muzikos valdininkų klasė klestėjo dar iki Zhou dinastijos ir buvo atsakinga už šalies muziką, ritualus ir švietimą. Konfucijaus, kaip ruistų klasės atstovo, dèka šie trys vektoriai (muzika, ritualai ir švietimas) tapo konfucianizmo pamatiniais principais. Taigi muzikos svarba ankstyvajame ir vèlesniame konfucianizme turi gilias istorines priežastis.

\section{IVADAS}

Kinijos centrinè televizija (KCTV) palyginti neseniai parodè populiarią muzikinę laidą Klasikos dainavimas 經典詠流传
(Tái: 2019). I laidą televizija pakvietė beveik šimtą iškilių Kinijos muzikantų ir kitu garsenybiu, kurie interpretavo kla-

RAKTAŽODŽIAI: Konfucijus, ankstyvieji konfucianistai, ruistai, muzika, mperatoriškieji muzikos valdininkai.

KEY WORDS: Confucius, early Confucians, ruists, music, imperial music officials. 


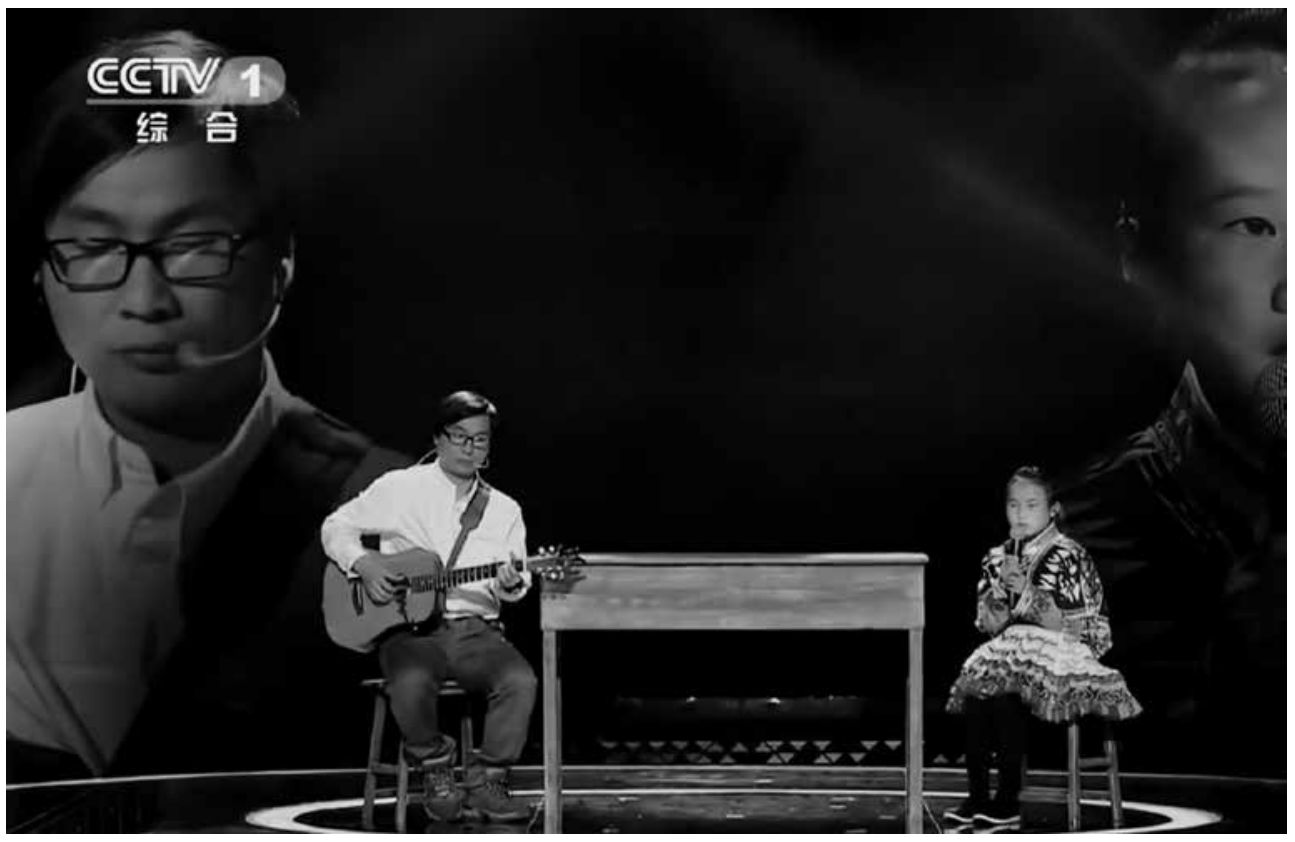

Paveikslas 1. Viena populiariausių ir emocionaliai paveikių laidoje Klasikos dainavimas atliktų dainų - "Tái“ (liet. „sąmanos“) pagal Qing dinastijos (1644-1911) autoriaus Yuán Méi 袁枚 poezijos žodžius. Dainavo mokytojas kartu su savo studentais atvykę iš Guizhou 贵州 provincijos. Poetas kalbejjo apie tai, jog kiekvienas žmogus, kad ir koks paprastas ir kuklus jis būtų, yra tartum tos sąmanos, kurios, nors ir niekada nematė saulès šviesos, bet vis tiek turi grožio ir svajonių

siką perdainuodami ją kaip modernius kūrinius liaudies baladžių, populiarių dainų ar netgi rokenrolo stiliais. Šis TV "show" buvo rodomas atspindint dabartinę oficialią šalies politiką vadinamą „Kinų tradicinès kultūros atgimimu“. Igyvendinant šią politika, plačioji šalies visuomenė nuosekliai supažindinama su didingas tradicijas turinčia klasikine kinu poezija, tokiu būdu per „populiarių dainų dainavimą" atgaivinamos ,tradicinès kinų vertybès". Šis plačiujuç liaudies masių švietimo būdas pasitelkiant muziką ir literatūrą yra tvirtai ịsišaknijęs konfucianizmo sąvokoje jiào huà 教化 (liet. "transformacija per švietimą"). Reikšmingu Kinijos civilizacijos istorijos tarpsniu plataus masto švietimas per muziką praktiškai visada buvo naudojamas kaip galingas įrankis, turintis didžiules potencines galimybes pakeisti žmogaus dvasią ir kartu visą visuomenę. Po intensyvių, vis dar tris dešimtmečius trunkančių modernizavimo reformų laidos Klasikos dainavimas populiarumas rodo aktualejjanti visuomenèje tradicinių konfucianizmo vertybiu poreiki, vertybiu, kurios formavo kinų kultūrą ir visuomenę daugiau nei du tūkstančius metų.

Muzikos pojūtis iš tikruju yra svarbi žmogiškos prigimties dalis. Šis pojūtis dažnai apibūdinamas kaip universali žmonijos „kalba“. Knygoje Muzikofilija psichologas Oliveris Sackas pabrèžia: „Polinkis i muziką pasireiškia jau kūdikystèje, taip pat vaidina pagrindini vaidmenį kiekvienoje kultūroje, ir greičiausiai užgimė žmonijos kaip rūšies pradžioje" 
(Sacks 2008: xi). Kitaip tariant, būti žmogumi reiškia turèti potrauki prie muzikos. Ankstyvieji konfucianistai puikiai žinojo apie šią muzikos svarbą ir emocinio poveikio galią žmonijai. Noredami sukurti tobulesnę visuomenę, jie žiūrëjo i̇ muziką kaip ì itin svarbu veiksni, turinti galią puoselèti žmogaus charakteri ir elgesi. Muzikos derinys su meile tẻvynei arba asmeninėmis svajonėmis yra lengvai priimamas kinų kultūroje ir dažnai susiejamas su jau minèta jiào huà 教化 sąvoka. Priešingai nei kai kuriose kitose kultūrose, kur muzika suprantama kaip vien tik asmeninè ir pramoginè, ar iracionali ir nelogiška, konfucianistai tvirtino, kad muzika yra pamatinis ir efektyvus būdas išreikšti teigiamas vertybes bei reformuoti pasauli, ji atliekanti socialumą kuriančios socialinès gramatikos funkciją (Garrison 2012: 209-222).

Konfucianistai siekè igyvendinti žmogiškumo etinị idealą rén 仁 praktikuodami $l i$ 禮 (ritualizuotos etinès "taisyklès“) ir yuè 樂 (muzika), dèl to konfucianistinè kultūros tradicija dar būna dažnai vadinama Ritualo ir Muzikos kultūra lǐ yuè wén huà 禮樂文化. Kaip pažymėjo sinologai Rogeris Amesas ir Henris Rosemontas, glaudžiai tarpusavy susiję ritualas ir muzika Kinijoje tūkstančius metu, nuo senovès iki dabartinių laiku padèjo kaip socialinè gramatika (Ames, Rosement 1988: 56-57). Nuodugniau tyrinèjant iki Qin dinastijos (iki 221 m. pr. Kr.) laikotarpio filosofu požiūri i muziką, galima kelti klausima, kodèl būtent konfucianistinè mokykla, lyginant ją su tuometinemis kitomis mokyklomis, iš muzikos skolinasi harmonijos sąvoką ir kartu taip smarkiai vertina muzikos vaidmeni ugdant asmenybę ir formuojant visuomenę? Juk anot daoistinès mokyklos, „penki muzikos garsai apkurtina žmogü“1 (Laozi 1997: 29, Chen 1984: 45), legalistinè mokykla kritikavo muziką sakydama, kad „šventujų netrikdo penkios spalvos ir jie nesimégauja muzika, o išmintingas valdovas žino, kaip laikytis atokiau nuo pramogu ir išlikti paprastam“2 (Wang 1998: 145), o ką jau kalbèti apie moistus, kurie tiesiai sakè, kad „muzika yra blogai“"3 (Sun 2001: 251). Tarp ivvairiu šių skirtingų mokyklų konfucianistinis entuziazmas ritualo ir muzikos atžvilgiu labai išsiskiria.

Taigi čia keliame pamatini klausimą apie ankstyvuosius konfucianistus: dèl kokiu priežasčiu konfucianizmas ir muzika buvo ir vis dar tebèra taip glaudžiai susiję? Kodèl būtent konfucianistai, kitaip nei kitos mokyklos, taip aukštai vertino muzikos pozityvią socialinę galią? Ieškodami atsakymu $i$ šiuos klausimus mes remiamės sena, tačiau vis dar gyva prielaida, kad konfucianistai kilo iš Vakaru Zhou dinastijos (1046-771 m. iki Kr.) muzikos valdininkų yuè guān 樂官 luomo. Jei ši prielaida yra teisinga, tada ị iškeltus teorinius klausimus apie konfucianistinio ritualo ir muzikos kilmę galima suformuluoti gerai pagristus atsakymus.

\section{ANKSTYVIEJI KONFUCIANISTAI IR ŠAMANAI}

Pats terminas konfucianizmas dažnai suklaidina kiniškai nekalbantị skaitytoją ar netgi tyrinètoja, kadangi lengvai susidaro klaidingas įspūdis, kad konfucia- nizmas tikriausiai yra būtent Konfucijaus sukurta religija, filosofija ar mokymas. Tačiau kinų kalboje tradicija, kurią mes lietuviškai vadiname konfucianizmu ir 


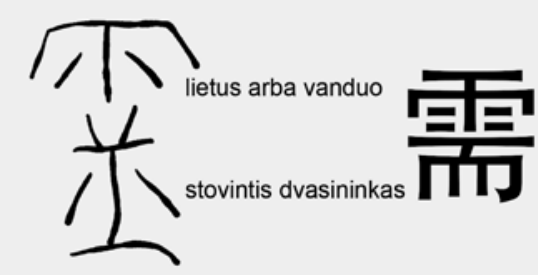

Paveikslas 2. Orakulo rašmuo xū 需, atvaizdas stovinčio lietuje

siejame su Konfucijaus vardu, kiniškai vadinama žodžiu, kuris etimologiškai neturi nieko bendra nei su Konfucijaus pavarde "Kǒng“ 孔, nei su jo kitais vardais "Zhòngní" 仲尼 ar titulais "Kǒng füzi “孔夫子 (liet.: mokytojas, Kong). Minties ir veiksmo mokyklą, kuriai priklausè Konfucijus, kinai ipprastai vadino Rúxué 儒學 (liet.: Ru mokymas). Todèl galima sakyti, kad Rú mokymas bei Konfucijus Kǒng ž̌ 孔子 priklauso dviem gan skirtingiems semantiniams pasauliams.

Sąvoka rú 儒 buvo suprantama kaip tam tikra konkreti grupè žmonių arba net kaip savotiškas karjeros kelias, kuris egzistavo kelis ar net keliolika šimtmečiu anksčiau, nei pasaulyje pasirodė Konfucijus. Šiai grupei priklausė žmonès, kurie dirbo valdžios administracijoje arba tiesiog vietinio vasalo dvare ir kurie buvo istorijos, literatūros, o ypač astrologijos ir meteorologijos sričių žinovai. Jie, kaip žmonès, sugebantys prognozuoti ateinanti lietaus ar sausros laikotarpi, vaidino lemiamą vaidmeni senovès Kinijos gyvenime, smarkiai susijusiame su žemès ūkiu. Sugriuvus Zhou dinastijai, laikotarpiu nuo VII iki V šimtmečio pr. Kr. daugybẻ priklausiusių aukštesnei klasei mokytoju, ar netgi kai kurie valdovu klasès nariai, tapo plebejjais ir ėmė uždirbinèti pragyvenimui mokydami klasikos arba atlikdami tokias ceremonijas kaip vestuvės ir laidotuvès. Visi šie žmonès tais laikais buvo vadinami rú 儒, ir tik daug vèliau Konfucijus, remdamasis šia šimtmečius gyvavusia rú xué 儒學 tradicija, kūrè ir plètojo savo mokymo sistemą. Dèl jo veiklos iš esmès pasikeitè rú 儒 sąvokos prasmè. Pamažu ši sąvoka èmè reikšti ne tam tikrą karjerą ir profesija, kaip anksčiau, bet savitą socialini statusą su konkrečia kultūrine tapatybe.

Čia svarbu paminèti, kad kai straipsnyje rašome apie ankstyvają rú 儒 grupę, mes ir laiko, ir vietos atžvilgiu turime omenyje visai ką kita nei vadinamuosius „ankstyvuosius konfucianistus“ - ši terminą dažnai galime aptikti Vakarų sinologu straipsniuose. Straipsnyje ankstyvaisiais rú 儒, arba ruistais, mes vadiname dar iki Konfucijaus egzistavusią ypatingą socialinę klasę žmonių, o ne Pavasario ir Rudens laikotarpiu (770-476 m. pr. Kr.) mokytojo Kǒng 4 suformuotos naujos minties ir veiksmo mokyklos sekejjus, vadinamuosius konfucianistus.

Kadangi kiniški rašmenys nuo jų sukūrimo praktiškai nepasikeitè, etimologinè analizė yra patogus ir efektyvus būdas tyrinèti senovès Kinijos visuomenę. Hieroglifo rú 儒 kairioji pusè yra sudaryta iš raktinès dalies $\}$ (liet. žmogus), o dešinioji - $x \bar{u}$ 需 (liet. poreikis), ir šios dvi dalys kartu sudaro hieroglifa, reiškianti „,ta, kuris dirba pagal kitú poreikius". Toliau analizuodami dešiniąją $x \bar{u}$ 需 dali matome, kad ji vaizduoja žmogu, stovintį arba šokantị lietuje. Orakulo rašmenu žodynas 甲骨文字典 (Yu 1999) kildina $x \bar{u}$ 需 iš žmogaus, stovinčio lietuje ar po vandens srove, atvaizdo, kur vanduo teka iš abieju kūno pusių ir tikriausiai vaizduoja maudymąsi arba prausimąsi (žr. pav. 2). 

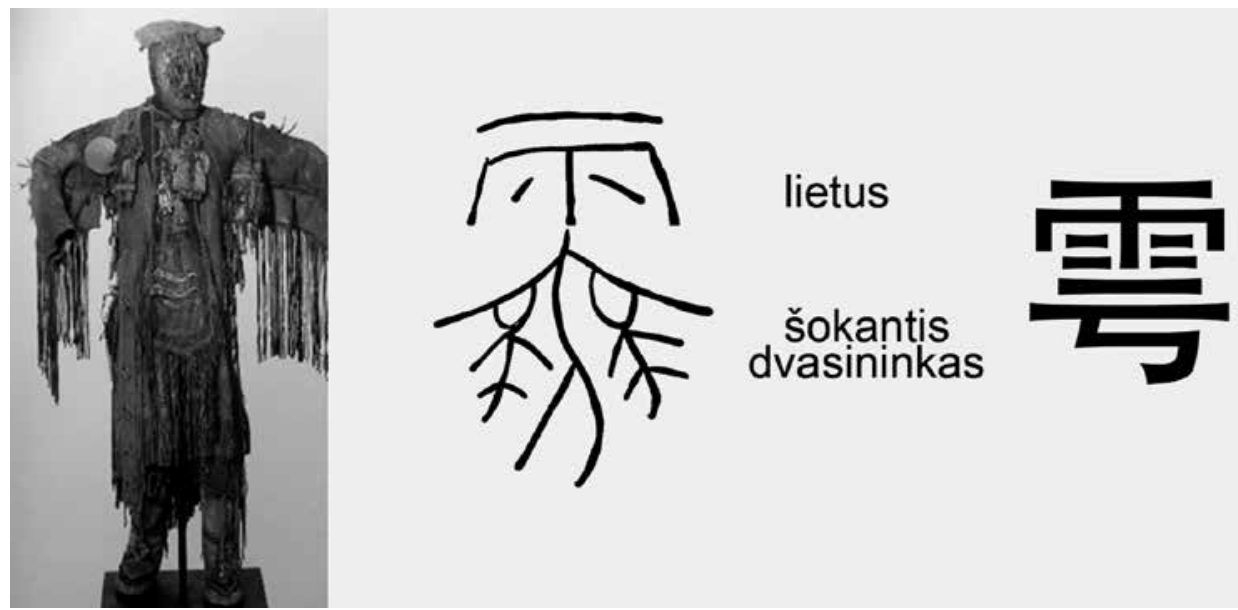

Paveikslas 3. Šamano dvasininko rūbų fotografija bei Yú 零 rašmuo, parašytas Orakulo rašmenų šriftu. Čia palyginti akivaizdi Yú kaip šamano dvasininko, šokančio lietuje, prasmė

$X \bar{u}$ 需 atvaizdas, kuriame vaizduojamas žmogus lietuje, susieja rašmeni su tų laikų dvasininku-šamanu, kuris atlikdavo ritualini apsivalymą norèdamas išreikšti pagarbą ir nuoširdumą dievybei ar dangui. XX a. pradžios garsus kinu akademikas Zhāng Tàiyán 章太炎 straipsnyje „Diskusija apie nacionalini paveldą" 國故論衡 pažymèjo, kad rašmuo rú 儒 yra kilęs iš $x \bar{u}$ 需 (liet. poreikis), kadangi $x \bar{u}$ 需 viršutinė dalis reiškia „lietų“ $y u ̌$ 雨 (Zhang 2008: 68). Taigi ankstyvieji konfucianistai ar, tiksliau, ankstyvieji ruistai, buvo savotiški meteorologijos žinovai, kurie galëjo nuspèti potvynių ir sausros laikotarpius ir kurie vaidino religinį dvasininko-šamano vaidmenį. Vèliau žodis rú tapo 儒 „žmogaus su profesija ir išmanymu“ sinonimu, taigi „konfucianistu", t. y. ruistu rú 儒.

Yra dar ir kitas rašmuo yú 雲, glaudžiai susijęs su ruistais ir etimologiškai panašus i $x \bar{u}$ 需. $Y u$ 零 yra dar panašesnis ị šokantị lietuje dvasininką nei $x \bar{u}$ 需 (žr. paveikslą 3). Veikalas Zhou ritualai
周禮 $(Z h \bar{o} u$ Ľ̌ šitaip apibūdina yú 零 šokį: „kai šali ištinka sausra, dvasininkas, idant iškviestų lietų, turi sušokti yú 零 šoki “ ${ }^{\prime 5}$ (Zhouli 1922). Konfucijaus Pašnekesiuose aprašyta garsioji istorija apie yú 雲, kai Konfucijus klausia savo mokinių, ko jie norètų:

Galiausiai Mokytojas paklausè Zēng X̄̄ (pravarde Dian): „Dian, o ką tu norètum daryti?" Dian, nustodamas groti liutnia, kol ši vis dar skambejo, padejo ją i šoną ir pasakè: „Mano norai skiriasi nuo kitų trijų mokinių.“ Mokytojas: „Kas gi čia bloga? Kiekvienas laisvai išsako tai, ko nori.“ Dian atsakè: „Ši paskutini pavasario mènesi, kai žaluma visur jau suvešèjo, kartu su penkiais ar šešiais jaunuoliais, kurie ką tik perejjo brandos rituala bei šešiais ar septyniais berniukais aš išsiprausčiau $Y i$ upejje, šokčiau $Y u$ šoki, džiaugčiausi vejjo dvelksmu tarp lietaus altorių ir grį̌žciau namo dainuodamas". Mokytojas atsiduso ir tarè: "Aš pritariu Dian" (Konfucijus 2004: 1696; Ames, Rosemont 1998: 150).

Nežinant apie aptariamą ryši tarp ruistu ir Zhou dinastijos šamanų dvasi- 
ninkų, mokančių iššaukti lietų, šis Pašnekesiu fragmentas apie mokini, svajojanti sušokti ritualini šokị, daugeliui liktų nesuprantamas ir iškritęs iš konteksto. Siekdamas sušokti yú 零 šoki, dainuoti ir groti liutnia, Zēng X̄̄ (Diăn) igyvendina "tradicinị" ruisto idealą ir būtent dèl to gauna savo mokytojo Kong visapusišką pritarimą.

Etimologiškai tyrinėdami su rú susijusius Shang (1600-1046 m. pr. Kr.) ir Vakaru Zhou (1046-771 m. pr. Kr.) dinastiju laikotarpio Orakulo ir Bronzos rašmenis matome, kad rú nurodo ì grupę ankstyvųju konfucianistų (ruistu) iki Konfucijaus. Be to, $x \bar{u}$ 需 ir yú 零 analizè atskleidžia glaudžias sąsajas tarp ankstyvuju ruistu ir šamanų dvasininkų, kurie buvo atsakingi už žmonių bendravimą su dangumi ritualo, šokio ir muzikos būdu.

Zhou ritualu 《周礼·春官》 knygoje Pavasario valdininku dalyje 《周礼·春官》 kalbama apie vadinamuosius bǔ guān 卜 官 (liet.: pranašavimo valdininkai-meistrai), kurie buvo atsakingi už žemesnio rango pranašavimo valdininkus ir už tam tikrą šios kategorijos valdininkų elgesio kodeksą (Zheng, Lu 1922: 9-14). Remiantis šiuo kodeksu, jei šali ištinka sausra, pranašavimo meistrai vyrai turi sušokti yú šokį. O pranašavimo meistrès moterys turi atlikti tam tikrus ritualus fú chú 袚除 (liet. pavasario apsivalymas), xìn yù 衅浴 (liet. žolių dušas) ir hàn hàn
旱暵 (liet. lietaus malda). Šių ritualų metu moterys, kaip ir vyrai, taip pat turi sušokti yú šoki. Dèl šių istorinių įrašų mes žinome, kad ankstyvojoje Kinijos administracijos sistemoje ritualai, muzi$\mathrm{ka}$, pranašavimas ir istorija buvo tarpusavyje susiję. Ankstyvieji ruistai būtent ir kilo iš šios Pavasario valdininku grupès ir toliau tęsè turtingą ritualų, muzikos ir yú šokio tradiciją.

Muzikos meistrai buvo atsakingi ne tik už lietaus prišaukima, bet atliko ir svarbų vaidmeni prognozuodami ịvairius šalies karinius ir politinius reikalus. Zuozhuan《左传·襄公十八年》veikale rašoma:

Kai Jin šalies žmonės sužinojo apie Chu šalies karių greitą pasirodymą meistras Kuang (Jin šalies vienas garsiausių grojančių muzikos instrumentais mokytoju ir valdininkų) patarè visiems nurimti sakydamas: „dainavau Šiaurès vèją taip pat ir Pietų vejją. Pietų vejjas buvo silpnas ir jo garsuose bylojo mirtis, todèl žinau, kad Chu šalis negali laimèti karo“ (Yang 1984: 1043).

Taigi šalies svarbūs reikalai, aukojimas dievams ir kariniai reikalai šiuo atveju buvo sprendžiami meistro Kuang 師礦 ritualinès muzikos būdu. Meistro Kuang karo pasekmiu prognozè yra vienas geresnių pavyzdžiu, aprašančių muzikos valdininkų atliekamą aukojimo ritualų veiklą.

\section{MUZIKOS VALDININKAI}

Šimtas mokyklų Kinijoje kilę iš valdininkų luomo. Kinijos istorikai jau seniai aptarinejja ankstyvųjų ruistu ir kitų mokyklų kilmę. Todèl be šių rú, $x \bar{u}$ ir yú rašmenų etimologinès analizès argumentų, kinų kultūros istorijoje yra ir daugiau literatūrinių konfucianizmo kilmès įrodymų. Han dinastijos laikotar- 
piu tyrinètojai mėgino surasti tikrąsias iki Qin laikotarpio buvusiu „,šimto mokyklų" atsiradimo ir suklestejjimo priežastis. Nors galutinai tos priežastys nebuvo nustatytos, bet Vakaru Han (202$263 \mathrm{Kr} . \mathrm{m}$.) dinastijos laikotarpio klasikas Liú Xinn 刘歆 (50-23 m. pr. Kr.) ir kiek vèliau istorikas Bān Gù 班固 (32$92 \mathrm{~m}$. po Kr.) tvirtino, kad „visi šimto mokyklų meistrai kilę iš karališkosios valdininku grupès" ${ }^{\prime 7}$, ir šis ju teiginys yra pakankamai pagrisstas. Liú Xīn savo straipsnyje "Septyni Štrichai" 七略 (Qī Lüè) iškèlè hipotezę, kad „,ankstyvieji konfucianistai buvo Zhou dinastijos valdininkai“. O Bān Gù 班固 panašiai pateikè šią idèją savo Han istorijoje 漢書 (Hàn Shü) sakydamas, kad „ne tik konfucianistai, bet visos iki Qin minties mokyklos buvo kilusios iš Zhou karališkosios valdininkijos:

Manoma, kad konfucianistai kilo iš valdininkų Sī Tú (tụ, kurie tvarko demografinius reikalus, fermų žemes ir atsako už vietini švietimą); daoistai kilo iš valdininkų Shǐ Guān (tư, kurie atsakingi už valdiškus dokumentus ir istoriją); Yin-Yang mokyklos atstovai kilo iš valdininkų $X_{\overline{1}}-$ Hé (senovès astrologai); legalistai - iš teisèjų valdininkijos; o Vardų mokyklos atstovai - iš valdininkų Ľ̌ Guan (tų, kurie dalyvauja kaip ceremonijų meistrai); Moistai tuo tarpu kilo iš senovès šventyklų sargų (Ban 1962: 1728-1746).

Ši hipotezė yra žiūros taškas, kuriuo remiantis galima buvo paaiškinti, iš kur trečiame šimtmetyje iki Kristaus Kinijoje atsirado tiek daug klestinčių mąstymo mokyklų. Turint omeny tai, kad antikos laikais aristokratija praktiškai monopolizavo literatūrą ir žinias, ši mintis, jog dauguma mokyklu kilo iš Zhou biurokratinès sistemos, atrodè pagrista ir priimtina. Zhou ritualu 《周禮》 knygoje biurokratine sistema yra gana konkrečiai aprašyta, ir ši sistema labai smarkiai paveikè tolesni Kinijos kultūrinès galios augimą. Anot $\mathrm{Zhou} \mathrm{Li,} \mathrm{ru-}$ istai buvo "triju ritualu“" pagrindine mokykla, arba didesnès sistemos dalis. Ši sistema susidejo iš penkių didelių grupių. „Dangaus“ (astronomijos, astrologijos, meteorologijos) valdininkijos grupè turëjo 63 valdininkus, atsakingus už skirtingus dalykus (tai buvo pagrindinè šalies valdininkija, kuri taip pat tvarkẻ finansus ir visus karališkuosius reikalus); toliau „Žemès“ valdininkijos grupè (78 valdininkai, atsakingi už žemès ūkị, vietinį švietimą ir mokesčiu rinkimą); „Pavasario“ valdininkijos grupé (70 valdininku, atsakingų už šalies ritualus ir etiketa, religines apeigas bei aristokratijos švietimą); "Vasaros“ valdininkijos grupè (69 valdininkai, atsakingi už karybą); „,Pavasario“ valdininkijos grupe (66 valdininkai, atsakingi už šalies teisinę sistemą ir jos tvarkymą, taip pat už kalèjimų ir bausmių sistemą). Remiantis Han knyga, buvo manoma, kad ruistai priklausè Sī tú 司徒 valdininkijos grupei (arba "Žemès“ valdininkijos grupei), o dabartiniais laikais manoma, kad vadinamieji Muzikos Meistrai, arba Zhou ritualu knygoje aprašomi „Pavasario“ valdininkai, priklausantys Muzikos valdininkijos grupei, buvo vienas svarbiausių ankstyvųjų ruistu kilmės židinių. 


\section{ANKSTYVIEJI MUZIKOS VALDININKAI}

Viename iš ankstyviausių Kinijos civilizacijos veikalu, vadinamojoje Dokumentu knygoje 尚書 (Shàng Shü), yra aprašyta garsi istorija apie muzikos, poezijos ir šokio pradžią:

Shun imperatorius pasakè: „Kui, aš paskiriu tave būti Muzikos Vadovu ir mokyti mūsu sūnus taip, kad tiesmukiški būtų kartu ir romaus būdo; kad švelnūs būtụ orūs, o stiprūs nebūtu tironiški, o smarkaus charakterio - nebūtu arogantiški. Poezija yra nuoširdžiausios minties išraiška; dainavimas yra tos išraiškos tęsinys; natos lydi dainavimą ir jos yra suderintos tarpusavyje. (Šiuo būdu) aštuoni skirtingi instrumentụ tipai gali būti taip suderinti, kad vienas kitam netrukdytu, o dvasios ir žmonès sueitu i harmoniją. Kui atsakè: „Aš nesmarkiai suduodu ì skambantị akmenį, ir ịvairūs gyvūnai veda vienas kitą šokti“" (SHANGSHU 1994: 9).

Imperatorius Shùn 舜 paskyrė Kuí 竞 muzikos valdininku, taip pat atsakingu už poetini švietimą bei ritualini šokị. Kuí, būdamas muzikos valdininku, kartu buvo ir mokytoju (,mokyti mūsu sūnus“) bei šokejju-dvasininku (,ivairūs gyvūnai veda vienas kitą šokti“). Kaip vienas svarbiausių konfucianistinės kla- sikos veikalų šis Dokumentu Knygos fragmentas parodo, kaip ankstyvojoje visuomenëje buvo integruota muzika, šokis ir poezija. Vèliau panašią tvarką perémè konfucianistinès mokyklos atstovai.

Iki Qin minties mokykluc dokumentuose netrūksta fragmentu, kur aptariami muzikos valdininkai bei pati muzika. Zhou ritualuose, Pavasario valdininku dalyje《周禮·春官》muzikos valdininku aprašymas buvo perimtas iš Dokumentu knygos 《尚書》 tradicijos apie Kui, atsakingą už muzika, šokị ir švietima, be to, ten buvo detaliai išvardintos valdininkų grupès (Pavasario valdininkai), atsakingos už ritualų ir muzikos sistemą. Tarp $P a-$ vasario valdinininku buvo 70 skirtingu administraciniu pareigybių. Pareigybes bendrais bruožais galima suskirstyti i keletą grupių: 1) Zongbo grupé (Protėvių garbinimo sistema, šeimos, vyresniuju vadovu ir aukliu pareigos); 2) Muzikos valdininku grupe; 3) Pranašavimo arba divinacijos grupé; 4) Istoriku grupé; 5) Dangaus reiškiniu grupe bei 6) Diplomatijos grupe. Pagal Zhou ritualu aprašymą pateikiame valdininkų pareigybiu lentelę, iš kurios galima suprasti Pavasario valdininku administracinę struktūrą:

\begin{tabular}{|c|c|}
\hline $\begin{array}{l}\text { VALDININKŲ } \\
\text { GRUPE 禮官系列 }\end{array}$ & PAREIGYBIŲ APRAŠYMAS \\
\hline $\begin{array}{l}\text { Da Zong Bo } \\
\text { 大宗伯 }\end{array}$ & $\begin{array}{l}\text { Ritualinių ceremonijų, susijusių su dangaus dievybiu, žmonių, } \\
\text { dvasių ir žemės dievybių, i̇steigimas ir palaikymas siekiant padè- } \\
\text { ti imperatoriui palaikyti savo imperijoje tvarką bei stabilumą izai- } \\
\text { riose vidinėse karalystėse }\end{array}$ \\
\hline $\begin{array}{l}\text { Xiao Zong Bo } \\
\text { 小宗伯 }\end{array}$ & $\begin{array}{l}\text { Administruojama imperijos dievybių hierarchija: (sostinèje) deši- } \\
\text { nèje statomi altoriai žemės ir grūdu dievams, kairèje - šventyklos } \\
\text { protėviams }\end{array}$ \\
\hline
\end{tabular}




\begin{tabular}{|c|c|}
\hline $\begin{array}{l}\text { VALDININKŲ } \\
\text { GRUPE் 禮官系列 }\end{array}$ & PAREIGYBIŲ APRAŠYMAS \\
\hline 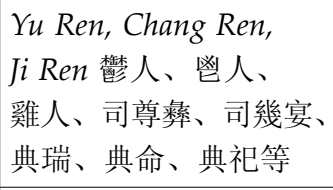 & $\begin{array}{l}\text { Atliekantys skirtingas pareigas aukojimo ceremonijose, taip pat } \\
\text { atsakingi už aukojimo gyvūnų priežiūrą ir paruošimą, aukojimo } \\
\text { indus, aprangą, vėliavas ir emblemas, taip pat šeimos kapų } \\
\text { apsaugą ir priežiūrą }\end{array}$ \\
\hline \multicolumn{2}{|r|}{ Muzikos valdininkai 樂官系列 } \\
\hline $\begin{array}{l}\text { Didysis muzikos } \\
\text { meistras } \\
\text { 大司樂 }\end{array}$ & $\begin{array}{l}\text { Didysis muzikos meistras yra visiškai atsakingas už imperatoriš- } \\
\text { kosios mokyklos švietima, taip pat už susijusių mokyklu įsteigi- } \\
\text { mą ir palaikyma, kur aristokratijos šeimų vaikai ir mokiniai gali } \\
\text { mokytis. } \\
\text { (Mokytojų kvalifikacija) Apima mokytoju paiešką ir įdarbinima, } \\
\text { turintys meno sugebejimu bei tam tikro moralinio lygio žmonės } \\
\text { paprastai priimami i tokias mokyklas, o jiems mirus, jie tampa } \\
\text { vėliau garbinamais muzikos protèviais. } \\
\text { (Mokymo turinys) Aristokratijos šeimų muzikos ir moralės mo- } \\
\text { kymas apima tokias savybes kaip lojalumas, charakterio tvirtumo } \\
\text { ir minkštumo pusiausvyra, pagarba, principingumas, pagarba } \\
\text { tėvams, broliškumo jausmo puoselejjimas. Muzika ir žodžiais im- } \\
\text { perijos sūnūs yra mokomi valdyti aristokratijai privalomą žodyną } \\
\text { ir sugebėjimus, muzika ir šokimu mokiniai turi išmokti konkrečius } \\
\text { šokius Debesu vartai, Didysis sukimasis, Didysis Xian, Didysis grožis, } \\
\text { Didžioji vasara, Didysis Yan, Didysis mūšis bei kitus šokius. Žinios } \\
\text { apie muzikos ritmą bei instrumentinio atlikimo palydimi šokiai } \\
\text { leidžia prišaukti žmonių dvasias bei dangaus ir žemės dievybes, } \\
\text { kurios padėtu kiekviename imperijos krašte sukurti draugiškus } \\
\text { santykius, liaudies harmonija, svečiu saugumą, tolimesnių kaimy- } \\
\text { nų susižavejjimą bei gyvūnijos klestėjimą }\end{array}$ \\
\hline \multicolumn{2}{|r|}{ Muzikos meistras 樂師 } \\
\hline & $\begin{array}{l}\text { Muzikos meistras atsakingas už pradinių mokyklų politika, be to, } \\
\text { moko aristokratijos šeimas kai kurių paprastų šokiu grupėse (pvz.: } \\
\text { šokis } F u, \text { plunksnu šokis, imperatoriškasis šokis, vėliavos šokis, } \\
\text { šokis su skydu, žmoniu šokis) }\end{array}$ \\
\hline $\begin{array}{l}\text { Didysis } x u, \\
\text { mažasis } x u\end{array}$ & $\begin{array}{l}\text { Didysis } x u \text { atsakingas už besimokančiujų kandidatų sąraša, kad } \\
\text { atejjus laikui, pavasari, jie būtu priimti mokytis, specialaus moky- } \\
\text { tojo mokomi šokti darniai ir pagal muzikos ritmą. Rudeni paskel- } \\
\text { biami besimokančiųjų rezultatai, taip pat siekiama toliau išmoky- } \\
\text { ti juos dainuoti unisonu pagal muzikos ritmą }\end{array}$ \\
\hline $\begin{array}{l}\text { Didysis meistras } \\
\text { ir paprastasis meistras }\end{array}$ & $\begin{array}{l}\text { Didysis meistras atsakingas už muzikos melodijų skaičiavimą bei } \\
\text { jų derinimą su yin yang principais, penkių garsų pakopų nustaty- } \\
\text { mą, taip pat už įvairių muzikos instrumentų gaminimą }\end{array}$ \\
\hline
\end{tabular}




\begin{tabular}{|c|c|}
\hline $\begin{array}{l}\text { VALDININKŨ } \\
\text { GRUPE 禮官系列 }\end{array}$ & PAREIGYBIŨ APRAŠYMAS \\
\hline $\begin{array}{l}\text { Orkestro dalyviai } \\
\text { Gumeng (Aklasis) 韾矇、 } \\
\text { Shiliao 視 瞭、 } \\
\text { Diantong 典同、 } \\
\text { Varpu meistras 磬師、 } \\
\text { Maoren 施人、 } \\
\text { Dianyongqi 典庸器 } \\
\text { bei kiti }\end{array}$ & $\begin{array}{l}\text { Gumeng atsakingas už būgnu, zhu, di, xun, xiao, guan ir styginiu } \\
\text { instrumentų grojimą bei dainavimą. Taip pat už poemu dainavimą } \\
\text { bei imperatoriaus bei kitǔ šeimų medžio surašymą. } \\
\text { Shiliao atsakingas už tai, kad atliekant muziką būtų mušamas } \\
\text { specialus dvipusis būgnas, taip pat kitas būgninis instrumentas, } \\
\text { vadinamas songqing (tik Kinijoje turimas tam tikras instrumentas, } \\
\text { gaminamas iš akmens), bei shengqing. Atsakingas už instrumentu } \\
\text { paruošimą didžiajam meistrui. Paprastai muzika visada buvo pa- } \\
\text { laikoma Gumeng. } \\
\text { Diangtong atsakingas už šešiu ritmų harmoniją, turi sugebėti } \\
\text { atskirti dangaus ir žemės, keturių šaliu, yin yang garsus, kad su- } \\
\text { derintu kiekvieno instrumento skambesi. } \\
\text { Maoren atsakingas už gabių muzikai žmoniu išrinkimą iš liau- } \\
\text { dies ir moko juos Siyi šokio. } \\
\text { Dianyongqi atsakingas už instrumentų ir jiems pagaminti skirtu } \\
\text { medžiagų saugojimą }\end{array}$ \\
\hline \multicolumn{2}{|r|}{ Pranašavimo (divinacijos) valdininkai 卜官系列 } \\
\hline $\begin{array}{l}\text { Pranašavimo didysis } \\
\text { meistras ir pranašavi- } \\
\text { mo meistras } \\
\text { 大ト、ト師 }\end{array}$ & $\begin{array}{l}\text { Pranašavimo didysis meistras Dabu pagal šalies svarbiausius reika- } \\
\text { lus surengia aštuoneriopo pobūdžio pranašavimus: } 1 \text { ) susijusius su } \\
\text { karyba; 2) susijusius su gamtos reiškiniais; 3) susijusius su labdara; } \\
\text { 4) susijusius su planavimu; 5) susijusius su pranašavimu, ar konkre- } \\
\text { tūs reikalai pasiseks, ar ne; } 6 \text { ) ar pavyks pasiekti konkrečią vietą 7) ar } \\
\text { lis, ar nelis; } 8 \text { ) ar žmogus pasveiks, ar ne. Pasitelkiant šiuos skirtingus } \\
\text { pranašavimus taip pat buvo interpretuojami trejopo pobūdžio žen- } \\
\text { klai, interpretuojamos trys „Permainų“ knygos bei aiškinamos trys } \\
\text { sapnų knygos, kad būtų galima prognuozuoti imperijos sėkmę ar } \\
\text { nesėkmę. Jeigu buvo gaunamas negeras ženklas, tai imperatoriui } \\
\text { buvo patariama imtis tam tikrų veiksmų imperijai gelbèti }\end{array}$ \\
\hline $\begin{array}{l}\text { Guiren, Shiren } \\
\text { ir Zhanmeng }\end{array}$ & 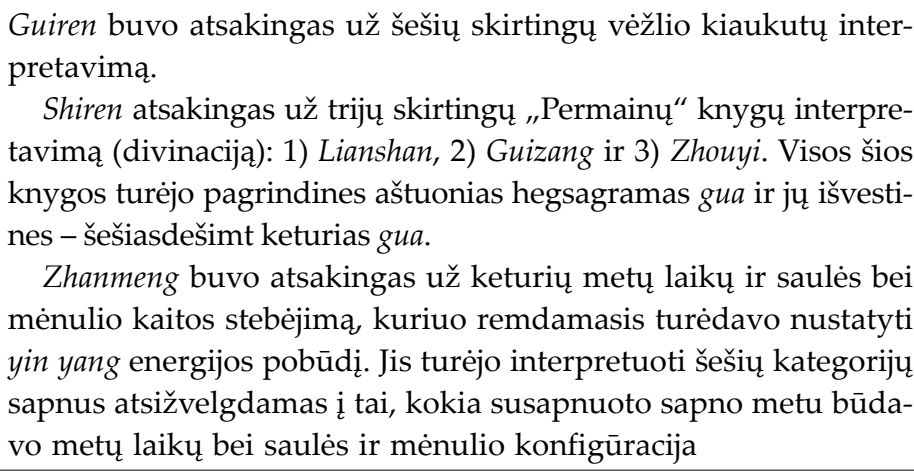 \\
\hline $\begin{array}{l}\text { Dàzhù ir Xiǎozhù } \\
\text { bei kiti }\end{array}$ & $\begin{array}{l}\text { Dazhu buvo atsakingas už šešių kategoriju specialiu žodžiu sukū- } \\
\text { rimą kurie buvo vartojami meldžiantis žmonių dvasioms bei dan- } \\
\text { gaus ir žemės dievybėms. Jais buvo prašoma gerovės, sėkmės bei } \\
\text { teisingo likimo }\end{array}$ \\
\hline
\end{tabular}


Šioje lentelèje bendrais bruožais išvardinti Zhou ritualu knygos Pavasario valdininku skyriuje aprašytų svarbiausiu valdininkų vardai ir pareigybės. Istoriškai žiūrint atrodo panašu, kad dar ankstesniais Xia 夏 (2070-1600 m. pr. Kr.) ir Shang 商 (1600-1046 m. pr. Kr.) dinastiju laikais tarp Pavasario valdininku buvo svarbiausi trys pagrindiniai žmonès: Ritualu valdininkas Ľ̈guān, Muzikos valdininkas Yuèguān ir Pranašavimų valdininkas Bŭguān. Jie turèdavo atlikti šalies svarbiausias su apeigomis susijusias pareigas. Prasidejus Zhou dinastijos laikotarpiui, šios kelių žmoniu pareigybės pamažu išsiplètojo į ištisą sudètingą valdininkijos aparata, kuris turejjo atlikti religines apeigas, ivvairius ritualus bei šviesti žmones. Vèliau, Rudens ir Pavasario laikotarpiu nykstant senajai sistemai, šie anksčiau buvę valdininkais žmonès perèmè kultūrinę tradiciją ir suformavo gana didelę rú grupę. Idëja, kad visi šimto mokyklų atstovai buvo kilę iš karališkų valdininkų, būtent Kinijos respublikos (1912-1949) laikotarpiu buvo gana plačiai palaikoma įvairių kinų tyrinètojų. Qianmu 錢穆 straipsnyje „Diskusija apie antikos istoriją" 古史辨 taip pat teigia, kad ankstyvieji konfucianistai buvo „tie, kurie turejjo specialius gebejimus ir buvo ìvaldę šešis menus" (Qian 1982: 1-2).
Taigi rú nebuvo vien tik Konfucijaus sekejjo pavadinimas.

Vèliau konfucianistai (kaip Konfucijaus sekejjai) perėmè ir tęsè Pavasario valdininku sistemos paveldą. Kalbant apie muzika, ji buvo tyrinejjama, atliekama ir perduodama būtent per rú mokyklą, o ne per atskirą vien tik muzika užsiimančiu žmonių grupę. Tai Kinijos muzikos istorijos fenomenas, kitaip tariant, Kinijos tradicinè muzikos kultūra nuo pat pradžių ir vèliau ilgą laiką buvo tvirtai laikoma konfucianistu rankose, o profesionalūs muzikantai ir atlikèjai neturèjo tokio statuso visuomenejje ir kultūroje, koks jiems buvo būdingas Vakaruose. Kinijos tradicinès muzikos teorijos tyrinèjimai buvo glaudžiai susiję su Dangaus keliu 天道, matematika, Gamtos ir žmogaus squeikos bei kitomis idèjomis. Kinu intelektualai i tai žiūrèjo kaip ị labai garbinga, turinti tam tikrą mistinį aspektą akademinį laimèjimą. 1583 m., Ming dinastijos laikotarpiu, tyrinëjant muzikos ir visatos reiškinių vidinę darną ir dèsningumus, pasitelkus kinišką abaką, buvo suskaičiuota mažoji sekunda $12 \sqrt{ } 2$, šitaip padedant lygiosios temperacijos pamatus visame pasaulyje, ir tai yra būtent konfucianistinès kultūros svarbus inašas i bendrą žmonijos muzikos kultūros lobyną.

\section{TRANSFORMACIJA IŠ VALDININKŲ | KONFUCIANISTUS}

Taigi turinčioje ilgą istorinę tradiciją rú grupeje Pavasario ir rudens laikotarpiu pasirodė mokytojas Kǒng (Konfucijus). Mokytojas Kǒng buvo rú tradicijos perèmejjas, sekejjas ir plètotojas, bet anaiptol ne jos sukūrèjas. Konfucijus pats tiesiogiai neskelbė savo vardu idèjų, tačiau tvarkydamas ir redaguodamas tradicinę rašytinę klasiką ir mokydamas savo mokinius, kūrybiškai įliejo savo mintị ir poelgius i jau esamą mąstymo tradiciją. Be abejo, tuo pačiu Konfucijus plètojo, tobulino ir aiškino rú tradicijos muzikos kultūros aspektus. Iš išlikusių Konfucijaus 
pasisakymų apie muziką matome, kad Konfucijus vengė diskutuoti ir tęsti šamanų kultūros mistinę muzikos ir šokių tradicija, tačiau tiesiogiai akcentavo Zhou dinastijos racionalios dvasios perspektyva, muzikos poveikị visuomenès darnai bei asmeniniam žmogaus tobulejimui. Pasak Konfucijaus, Zhou muzika buvo rú kultūros tapatumo ir esmès simbolis.

Konfucijus Pašnekesiuose duoda patarimą savo mokiniui Zǐ xià 子夏: „Būk kilnus rú, nebūk menkas rú" (Konfucijus 2004: 80; Ames, Rosemont 1998: 106). Iš šių žodžių matome, kad Konfucijus darè perskyrą tarp kilnaus ruisto ,jūnzi rú 君 子儒 ir menko ruisto „xiăo rén rú" 小人儒. Konfucijus neneigè, kad jo minties mokykla kilo iš ankstyvųjų dvasininkų luomo, kurie dirbo pranašais ir burtininkais, tačiau jis kartu akcentavo kitokio kelio paieškos svarba, teisingo kelio, kuris būtų pagrisstas ir tinkamas. Plačiai žinomas jo atsakymas i mokinio Zilu 子路 klausimą apie tarnavimą dvasioms ir vèlẻms: „Kol nežinai, kaip gyventi, kaip gali žinoti apie mirtį?" (Konfucijus 2004: 160; Ames, Rosemont 1998: 144). Rú buvo sena profesija iki Konfucijaus, bet būtent Konfucijus buvo tas žmogus, kuris perkeitè rú grupę iš konkrečios profesijos i gerbiamą socialinę klasę su ypatingomis žiniomis. Konfucijus yra pasakęs: „Mes turëjome tą pati šaltini kaip burtininkai ir istorikai, bet mes galiausiai pasirinkome kitą kelią" ${ }^{8}$ (Yan 2001: 5).

Po Konfucijaus, iki Qin 秦 ir Han 漢 dinastiju ruistai pamažu tapo akademikų-valdininkų grupe, kuri išsaugojo muzikos valdininku pareigas. Jie ilgainiui atsisakè muzikos kaip muzikos valdinin$\mathrm{ku}$ profesijos ir muziką vis labiau èmè naudoti kaip visuomenès dorovinio ugdymo ir mokymo instrumentą. Han dinastijos laikotarpiu, kai ruistu arba konfucianistų mokymas tapo ortodoksija, vienos iš šešiu klasiku -,,Muzikos klasikos"《樂經》-teksto visiškas praradimas tapo simbolišku posūkio tašku. Taigi nuo tada tai, kas nuo senovès laikų buvo perdavinëjama muzikos valdininku sistemoje apie muzikos mokslą ir su tuo susijusi matematini skaičiavima, nustojo būti visiems ruistams privalomas mokymas. Sugebejimas gèrètis muzika transformavosi i kultūros aspektą kaip asmeninio tobulëjimo organinè dalis, tuo pačiu tai tapo konfucianistams "gera muzika“.

Sugrižžkime trumpai prie paminètų šešių klasikinių tekstu - Giesmiu, Dokumentu, Ritualu, Permainu, Muzikos knygu ir Pavasario bei Rudens analų. Šių tekstų eiliškumas rodo mokymosi pakopų sunkumą. Manoma, kad Muzikos knygoje buvo aprašinëjami ankstyvujjų muzikos valdininkų profesionalūs muzikos gebëjimai, kuriems priklausė matematiniai metodai, skirti apskaičiuoti muzikos temperamenta, taip pat pranašavimo ir oro prognozių formulès. Nesunku suprasti, kodèl Muzikos kny$g a$ po Han dinastijos buvo prarasta, - ji buvo pernelyg sudètinga ir paprastiems akademikams nenaudinga.

\section{IŠVADOS}

Zhou dinastijos žlugimas maždaug IV šimtmetyje pr. Kr. leido rafinuotai aristokratijos kultūrai pasklisti tarp paprastu žmonių ir galiausiai padare itaką socialinès klasès shì 士 atsiradimui. Shì klasès atstovai turèjo laisvę mąstyti nebepriklau- 
sydami konkrečiai kilmingai šeimai, o tai leido Kinijos civilizacijos istorijoje išsiskleisti ir suklestèti didžiulei skirtingų humanitarinės minties ir veiksmo mokyklų ivvairovei. Pirmasis kinų kalbos žodynas Shuōwén Jiězi 說文解字 aiškino, kad rú - tai "žmogus, turintis amatą" (Ding 1988), vadinasi, ankstyvieji konfucianistai buvo tie, kurie paliko karališkuosius rūmus, pamažu tapo išsilavinusiais akademikais ir èmè uždarbiauti mokytojaudami arba dalyvaudami apeigose.

Vadinasi, etimologinè ir svarbiausiu kinų civilizacijos istorijos dokumentų studija rodo buvus glaudų ryši tarp muzikos valdininku, arba pirmujų imperatoriškujų dvasininkų, ir ankstyvujų ruistu dar iki Konfucijaus atsiradimo kinu civilizacijos erdvèje. Tik Konfucijui pasirodžius šios civilizacijos kultūrinèje „scenoje" minèta ruistu ideologijos tradicijas plètojanti socialinè grupè įsivyravo valstybès valdymo ir kultūros sistemoje bei išgarsejjo ir tapo jos dvasiniais lyderiais, arba socialiniu elitu. Taigi išsiaiškinus

\section{Literatūra}

Ames R. and H. Rosement. 1998. The Analects of Confucius: A Philosophical Translation. New York, USA: Ballantine.

Ban Gu 班固. 1962. Han knyga 漢書. Beijing: Zhonghjua shuju 中華書局.

Chen Guying 陳鼓應. 1984. Laozi, pastabos ir paaiškinimai. 老子今註今譯. Pekinas: Zhonghua shuju 中華書局.

Ding Fubao 丁福保. 1988. Shuowen jiezi egzegeze 說 文解字詁林. Beijing: Chonghua shuju 中華書局.

Garrison James. 2012. The Social Value of Ritual and Music in Classical Chinese Thought. Revista Internacional de Filosofía 31 (3).

Konfucijus. 2004. Konfucijus: pašnekesiai. Iš senosios kinų k. vertė Zita Mažeikaitè. Vilnius: Tyto alba.

Laozi. 1997. Laozi. Iš senosios kinų k. Vertė Dalia Švambarytè. Vilnius: Vaga. šiuos sudètingus kinų civilizacijos istorijos procesus paaiškèja, kodèl Ritualas ir Muzika yra pamatinės konfucianizmo sąvokos. Galiausiai mūsų glaustai aptartos muzikos valdininku pareigos ne tik nulèmè vèlesnes muzikos tendencijas, bet sąlygojo ir tai, kad per amžius konfucianizme išliko vidinis siekis visur ieškoti muzikinès galios ir harmonijos.

Taigi kaip matome iš atliktos analizès, šis istorinis ir genealoginis ryšys tarp Konfucijaus mokymo ir ankstyvuju ruistu bei šių kilmè iš imperatoriškujų muzikos valdininkų yra viena svarbesnių, o gal ir svarbiausia priežastis, nulèmusi gyvavusị tūkstantmečiais ir išlikusi iki šiol glaudų konfucianizmo ir muzikos ryši. Galima sakyti, jog konfucianistai, kitaip nei kitos mokyklos, labai vertino muzikos pozityvią socialinę galią būtent todèl, kad prioritetas muzikai per amžius buvo jų kraujyje ir prigimtyje. Todèl harmonijos ideja ir kiti pamatiniai konfucianistiniai principai, jų supratimas bei igyvendinimas yra neatsiejami nuo muzikos.

Qian $\mathrm{Mu}$ 錢穆. 1982. Ivadas $i$ diskusija apie senovés istorija. 古史辯序. Shanghai guji 上海古籍出版社. Sacks Oliver. 2008. Musicophilia: Tales of Music and the Brain. New York: Vintage Books.

Shangshu. 1994. Istorijos knyga 尚書. Tianjin: Tianjin guji 天津古籍出版社.

Sun Yirang 孫詒讓. 2001. Mozi 墨子閑詁. Beijing: Zhonghjua shuju 中華書局.

Tai 苔 (liet. Sąmanos). 2019. Prieiga per internetą: https://www.youtube.com/watch?v=lypRaMM ZUPY\&t=93s [žiūrèta 201908 08]

Wang Xianshen 王先慎. 1998. Hanfeizi raštu komentarai 韓非子集解. Beijing: Zhonghua shuju 中華 書局.

Yan Buke 閻步克. 2001. Muzikos meistrai ir istorikai valdininkai: tradicinés politinès kultūros ir politiniu sistemu straipsniu rinkinys 樂師與史官:傳統政治 
文化 與政治制度論集. Beijing: SDX Joint Publishing Company.

Yang Bojun 楊伯峻. 1981. Zuo istorijos egzegeze 春 秋左傳註. Beijing: Zhonghua shuju 中華書局.

Yu Xingwu 于省吾. 1999. Orakulo rašmenu egzegezé 甲 骨文字詁林. Beijing: Zhonghjua shuju 中華書局.

\section{Nuorodos}

1 Originale: “五音令人耳龍”.

2 Originale: “是以聖人不引五色, 不淫於聲樂, 明 君賤玩好而去淫麗”.

3 Originale: “為樂, 非也”.

4 Konfucijaus pavardè buvo Kǒng, dèl to Kinijoje jis dažnai ir buvo vadinamas „Mokytoju Kǒng”.

5 Vertejo pastaba: ateityje būtų vertinga palyginti kinų lietaus šamanus su lietuviškaja tradicija. Pasak mūsų garsaus religijotyrininko Gintaro Beresnevčiaus, lietuviai taip pat turejo tradicinių dainu, kurias dainuojant ypatingu būdu galima buvo prišaukti lietų. Pamenu, vienoje iš srautinių paskaitų maždaug 1995-1997 m. Beresnevičius lyg tarp kitko užsiminè, kad viename Suvalkijos kaimelių dar ir dabar yra dainininkų, kurie moka uždainuoti lietų prišaukiančią dai-
Zhang Taiyan 章太炎. 2008. Diskusija apie nacionalini pavelda 國故論衡. Beijing: Zhonghjua shuju 中華書局.

Zheng Xuan 鄭玄 ir Lu Deming 陸德明. 1922. Zhou ritualai 周禮. Chang Sha: Shangwu yinshuguan 商務印書館.

ną. Tačiau kadangi jie gerokai primiršo tradiciją, prišauktas lietus lyja tik apie penkiolika minučiu ir tokiu pernelyg ikypu kampu, dèl to yra netinkamas derliui.

6 Vert. pastaba: ar remdamasis Zitos Mažeikaitès Konfucijaus pašnekesiu vertimu, ar Dalios Švambarytės Laozi, lygiai kaip ir kitu vertimais, galiausiai pateikiu savo modifikuotą variantą atsižvelgdamas ị senovinès kinų kalbos originala, taip pat straipsnio kontekstą.

7 Originale: “诸子出于王官说”.

8 Originale: 吾與史、巫同途而殊歸也. Šis sakinys cituojamas iš knygos Zhou permainu knygos paaiškinimai, Bó Shū Yì Zhuàn 帛書易傳 veikale, rastame Mǎ Wáng Dū̄ 馬王堆 archeologinèse iškasenose $1973 \mathrm{~m}$.

Iš kinu k. vertė dr. Julius VAITKEVIČIUS, Nankino universitetas, Kinija 